\title{
Electromyographic Study of the Masseter Muscle After Low-Level Laser Therapy in Patients Undergoing Extraction of Retained Lower Third Molars
}

\author{
Estudio Electromiográfico del Músculo Masetero tras Terapia con Láser de Baja Intensi- \\ dad en Pacientes Sometidos a Extracción de Tercer Molar Mandibular Retenido
}

\author{
Fabio Moschetto Sevilha*; Tarcísio Eloy Pessoa de Barros ${ }^{* *}$; Gabriel Denser Campolongo*; \\ Tarley Pessoa de Barros*; Nilton Alves ${ }^{* * *} \&$ Naira Figueiredo Deana ${ }^{* \star *}$
}

SEVILHA, F. M.; DE BARROS, T. E. P.; CAMPOLONGO, G. D.; DE BARROS, T. P.; ALVES, N. \& DEANA, N. F. Electromyographic study of the masseter muscle after low-level laser therapy in patients undergoing extraction of retained lower third molars. Int. J. Odontostomat., 10(1):107-111, 2016.

\begin{abstract}
The surgery for extraction of the retained lower third molar is one of the most commonly performed procedures in the field of maxillofacial surgery. During this procedure, the surgical trauma can cause damage to the function of muscles involved in mandibular movements, such as the masseter muscle. In order to accelerate post-surgical recovery, many physiotherapy resources are employed, including laser therapy. The aim was to analyze the electrical activity of the masseter muscle treated with Low-level Laser (LLL) after surgical trauma. Assessments of masseter muscle on a sample of 60 patients were performed by surface electromyography in four instances: immediate preoperative, postoperative at 7, 14 and 21 days. The patients were divided into two groups: 1- untreated group with LLL in the postoperative; 2- group treated with LLL (810 nm; $10 \mathrm{~J} / \mathrm{cm}^{2}$ ) in the immediate postoperative and at 3, 6 and 9 days after surgery. On the seventh day after surgery $23.3 \%$ of the patients in the group receiving LLL showed recovery of their muscle activity as they presented in the immediate preoperative, versus only $3.3 \%$ of the untreated group. On the $14^{\text {th }}$ day, $73.3 \%$ of treated patients showed functional rehabilitation, versus $6.7 \%$ in the untreated group, and on the $21 \mathrm{st}, 80 \%$ versus $10 \%$ in the untreated group. On the $14^{\text {th }}$ postoperative day the electrical activity of the masseter muscle treated with LLL after surgical trauma was compatible with a condition of complete functional recovery. The findings of this electromyographic study indicated that LLL proved to be an efficient physiotherapeutic method for stimulating the masseter muscle functional recovery after surgery of retained lower third molars.
\end{abstract}

KEY WORDS: third molar, retained tooth, electromyography, low-level laser, masseter muscle.

\section{INTRODUCTION}

The surgery for extraction of the retained lower third molar is one of the most commonly performed procedures in the field of maxillofacial surgery. Third molars when impacted in bone, may cause inconvenience and are detrimental to oral health, which justifies their extraction (Cerqueira et al., 2004; Goldberg et al., 1985; Mercier \& Precious, 1992). The lack of space for the correct and functional positioning of third molars and orthodontic indication, are the main reasons for their removal. This procedure can lead to some complications, such as alveolitis, infection, bleeding, inferior alveolar nerve injury, pain and swelling (Berge, 1996; Garcia-Garcia et al., 1997; Norholt et al., 1998; Suarez-Cunqueiro et al., 2003). Furthermore, during this procedure the surgical trauma can cause damage to the function of muscles involved in mandibular movements, such as the masseter muscle (Alves \& Candido, 2013). The factors that contribute to these sequelae include those related to the inflammatory process initiated by the surgical procedure (Goldberg et al.). Due to these postoperative complications and seeking an increase in the speed of recovery many physiotherapy resources are employed, including laser therapy.

\footnotetext{
Departamento de Cirugía Maxilofacial, Facultad FACIG, Universidade Bandeirante de São Paulo, Guarulhos, Brasil.

"* Instituto de Ortopedia y Traumatología, Facultad de Medicina, Universidade de São Paulo, São Paulo, Brasil.

${ }^{* *}$ CIMA Research Group, Facultad de Odontología, Universidad de La Frontera, Temuco, Chile.

Kin* Kinesiólogo, Temuco, Chile.
} 
In the postoperative evaluation of the function of the masseter muscle (muscle affected after extraction), the clinical observation is predominant, but is subject to several different types of interpretation (Solberg, 1986). The surface electromyography is a scientific method of analysis with defined standards to evaluate the recovery time of this muscle. It is an appropriate method for evaluating the masseter muscle activity after third molar extraction surgery (de Barros et al., 2011). Electromyography is a noninvasive procedure easy to use, quick and painless and allows analysis of muscle function through analyzing the electrical signal produced during muscle contraction. The electric potential of the muscles can be recorded under normal conditions or following surgical procedures, under conditions in which damage of muscle function may occur (de Barros et al.; Hermens et al., 2000) to be understood, interpreted and recognized. Thus, this test provides health professional with a reliable and objective analysis, through monitoring and data logging of the mastication muscles (Campolongo et al., 2012). Electromyography can also help the surgeon assess whether physical therapy is required in each case, in order to accelerate the return to normality (Hermens et al.).

Among the recommended physiotherapy resources we have the low-level laser (LLL). The LLL, through the biomodulation action (Deep \& Horch, 2007), acts to control pain and inflammation against aggressors and accelerate the process of tissue repair. It acts in the body by controlling the release of prostaglandins, histamine and bradykinin inhibition (responsible for primary inflammation) and accelerates collagen production, ATP and local microcirculation. Also acts increasing the number of mitosis and protein synthesis, thereby increasing the speed of the tissue repair process, reducing the time to full recovery of the affected structures (Lizarelli \& Lizarelli, 2003), including the masseter muscle.

\section{MATERIAL AND METHOD}

This study was carried out with a sample determined by spontaneous demand for treatment, consisting of 60 patients with retained lower third molars aged 18 to 40 years. All patients underwent diagnostic tests consisting of physical and radiographic evaluation. The procedures for the extraction of the lower third molar had a maximum duration of one hour.
Electromiographic study. Miotool 400 surface electromyography device (Miotec) was used, connected to the masseter muscle to be studied (right or left) through individual double pediatric electrodes. The data were interpreted using the Miography software, from Miotec. The total examination time was 30 seconds, divided into alternating phases of five seconds each. The electromyographic signal was captured in four evaluations: 1 - between the $6^{\text {th }}$ and $7^{\text {th }}$ preoperative days. 2- between the $6^{\text {th }}$ and $7^{\text {th }}$ postoperative days. 3 - between the $13^{\text {th }}$ and $14 \mathrm{t}^{\text {th }}$ postoperative days. 4 - between the $20^{\text {th }}$ and $21^{\text {st }}$ days after surgery. The results of muscle activity were analyzed and compared, to estimate the recovery period. The descriptive results were expressed in means, standard deviation, minimum and maximum values.

Low-Level Laser Therapy. The patients were divided into two groups: 1- untreated group with LLL in the postoperative (control group); 2- treated group with LLL (Twin Laser Optics MM, $810 \mathrm{~nm}, 10 \mathrm{~J} / \mathrm{cm}^{2}$ ) in the immediate postoperative and at 3, 6 and 9 days after surgery.

Statistical analysis. Student's t test, Chi-squared, ANOVA and Tukey test were performed. A confidence level of $5 \%(=0.05)$ was adopted.

\section{RESULTS}

Table I shows that the two groups have statistically similar distributions of sex and operated side ( $p>0.999$ and $p=0.793$, respectively). The average age of the patients in treated LLL group was statistically higher than control group $(p=0.001)$.

Figure 1 shows reduction of electrical activity on the seventh day for both groups and also shows greater amount of electrical activity in the treated LLL group. The group undergoing laser seems to return to the preoperative value already on the $14^{\text {th }}$ day, while the control group on this day seems to present value still lower than the preoperative electrical activity.

Figure 2 shows that patients in the control group had mean electrical activity on the $7^{\text {th }}$ and $14^{\text {th }}$ days lower than preoperatively $(p<0.001)$ and only on 21 st day the average electrical activity of patients was statistically equal to the preoperative value $(p=0.171)$. In the treated LLL group, the electrical activity on the 
SEVILHA, F. M.; DE BARROS, T. E. P.; CAMPOLONGo, G. D.; DE BARROS, T. P.; ALVES, N. \& DEANA, N. F. Electromyographic study of the masseter muscle after low-level laser therapy in patients undergoing extraction of retained lower third molars. Int. J. Odontostomat., 10(1):107-111, 2016.

Table I. Characteristics of patients according to groups and results of statistical tests.

\begin{tabular}{|c|c|c|c|c|c|}
\hline \multirow{2}{*}{ Variable } & & \multicolumn{2}{|c|}{ Groups } & \multirow{2}{*}{ Total $(n=60)$} & \multirow{2}{*}{$p$} \\
\hline & & Control & Treated LLL & & \\
\hline \multirow[t]{2}{*}{ Sex n (\%) } & Female & $14(46.7)$ & $14(46.7)$ & $28(46.7)$ & \multirow{2}{*}{$>0.999^{*}$} \\
\hline & Male & 16 (53.3) & $16(53.3)$ & 32 (53.3) & \\
\hline \multirow[t]{2}{*}{ Side n (\%) } & Right & $17(56.7)$ & $18(60)$ & $35(58.3)$ & \multirow{2}{*}{$0.793^{*}$} \\
\hline & Left & $13(43.3)$ & $12(40)$ & $25(41.7)$ & \\
\hline Age (years) & Average (SD) & $21.8(3.0)$ & $26.0(6.0)$ & $23.9(5.2)$ & $0.001^{* *}$ \\
\hline
\end{tabular}

${ }^{*}$ Results of the chi-square test. ${ }^{* *}$ Results of Student's $t$ test. SD= Standard Deviation.

$7^{\text {th }}$ day was statistically lower than preoperatively $(p=0.001)$, but already on the $14^{\text {th }}$ day, the mean value of electrical activity of patients was statistically equal to the preoperative period $(p=0.978)$. At all time points, the mean value of electrical activity of the treated LLL group was statistically higher than the control group $(p<0.05)$.

In this study, $23.3 \%$ of the treated LLL group presented on the $7^{\text {th }}$ day, electrical activity equal to or greater than preoperatively, while in control group the percentage was only $3.3 \%$. On $14^{\text {th }}$ day, the percentage of patients using laser and returned to the preoperative value increased to $73.3 \%$ and in control group was only $6.7 \%$. On $21^{\text {th }}$ day still only $10 \%$ of control group showed electrical activity greater than preoperative value, whereas in the treated LLL group, the percentage was $80 \%$. The behavior of the electrical activity on the opposite side looks quite similar to the behavior on the working side (Figs. 1 and 2).

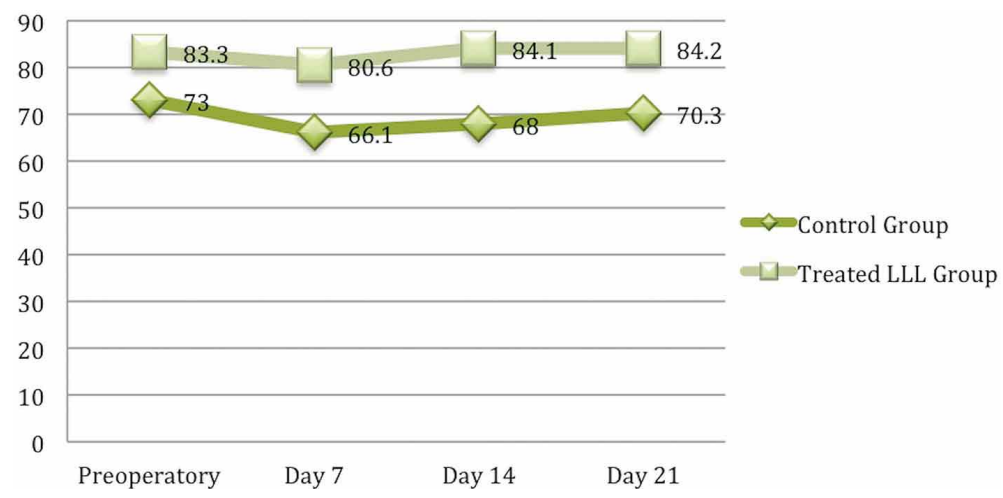

Fig. 1. Average profiles of electrical activity $(\mu \mathrm{V})$ second groups and time points.

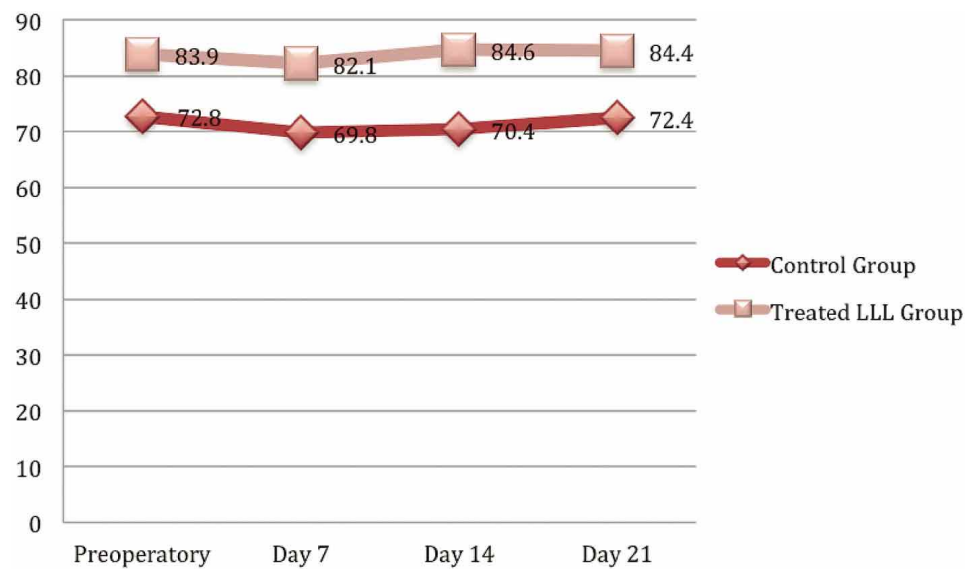

Fig. 2. Average profiles of electrical activity $(\mu \mathrm{V})$ second groups and time points in the opposite side of the surgery. 


\section{DISCUSSION}

The use of electromyography to study the masticatory muscles, especially the masseter, has been extensively discussed in the literature in specific areas such as physical therapy, orthodontics, temporomandibular dysfunction, and has shown satisfactory results, thus justifying accepting its use as a tool to assess muscle function pre and postoperatively (Bassanta et al., 1997; Markovic \& Todorovic, 2007; Learreta et al., 2004).

Even when properly indicated, the third molar extraction can lead to a number of complications. These complications may result from surgical procedures, due to the technique used in surgery, the degree of retention and surgeon skill, but they are always present, varying only in intensity (Brann et al., 1999; Laureano Filho et al., 2008). There is unanimity among authors regarding the most frequent of these: trismus, swelling and pain, causing difficulty and limitation of mandibular movements (Berge; Garcia-Garcia et al.; Mercier \& Precious; Norholt et al.). The masticatory muscles, which are innervated by trigeminal nerve, along with suprahyoid and infrahyoid muscles are responsible for mandibular movements (Alves \& Cândido). Muscular complications in the postoperative period after third molar extraction typically occur in the masticatory muscles, including the masseter muscle (Stolov, 1990). Anatomical knowledge of the region by the surgeon is also necessary to determine the degree of muscle involvement (Alves \& Cândido). The engagement of the muscular system can lead to a decrease from 15 $\%$ to $20 \%$ of the capacity of the mouth opening (Norholt et al.). There is undoubtedly, some loss of quality of life of patients due to these symptoms because they cause difficulty performing basic mandibular movements, chewing and phonation.

Seeking a reduction of post-operative complications and decreasing muscle recovery time, the use of low-level laser has achieved acceptance and credibility. The main effects attributed to this type of therapy are: the ability to accelerate tissue healing, improve bone repair and remodeling; restore normal nerve function after injury; modulate the inflammatory response by reduction of edema and modulate the immune system (Laureano Filho et al.; Markovic \& Todorovic; Matamala et al., 2014; Neiburger, 1999; Roynesdal et al., 1993; Viegas et al., 2005). With these characteristics, LLL could complement the antiinflammatory drug action and accelerate tissue repair in third molar surgery. Indeed, this hypothesis was tested in several studies with positive results. In the present study, we observed that the cumulative effect of the light emitted by LLL favored the increased speed of repair of the masseter muscle.

Considering our results we concluded that the recovery period, decreased significantly in the group treated with LLL compared with control group. On the $14^{\text {th }}$ postoperative day the electrical activity of the masseter muscle treated with LLL after surgical trauma was consistent with a condition of complete functional recovery. Furthermore, the findings of this electromyographic study indicated that LLL proved to be an efficient physiotherapeutic method for stimulating the masseter muscle functional recovery after surgery of retained lower third molars.

SEVILHA, F. M.; DE BARROS, T. E. P.; CAMPOLONGO, G. D.; DE BARROS, T. P.; ALVES, N. \& DEANA, N. F. Estudio electromiográfico del músculo masetero tras terapia con láser de baja intensidad en pacientes sometidos a extracción de tercer molar mandibular retenido. Int. J. Odontostomat., 10(1):107111, 2016.

RESUMEN: La cirugía para extracción del tercer molar mandibular retenido es uno de los procedimientos más realizados en el campo de la cirugía maxilofacial. Durante este procedimiento, el trauma quirúrgico puede causar daño a la función de los músculos involucrados en los movimientos mandibulares, entre ellos el músculo masetero. Con el objetivo de acelerar la recuperación postoperatoria, son utilizados muchos recursos de fisioterapia, incluyendo la terapia con láser. El objetivo de este estudio fue analizar la actividad eléctrica del músculo masetero tratado con láser de baja intensidad (LBI) después del trauma quirúrgico. Se realizaron evaluaciones del músculo masetero en una muestra de 60 pacientes, a través de electromiografía de superficie en cuatro momentos: preoperatorio inmediato, postoperatorio a los 7,14 y 21 días. Los pacientes fueron divididos en dos grupos: 1 - grupo no tratado con LBI en el postoperatorio; 2 - grupo tratado con LBI $\left(810 \mathrm{~nm} ; 10 \mathrm{~J} / \mathrm{cm}^{2}\right)$ en el postoperatorio inmediato y a los 3,6 y 9 días tras cirugía. Al séptimo día tras cirugía el 23,3 $\%$ de los pacientes del grupo tratado con LBI presentaron recuperación de su actividad muscular equivalente a lo presentado en el preoperatorio inmediato, frente a sólo el 3,3 \% del grupo no tratado. En el día 14, el 73,3\% de los pacientes tratados presentaron rehabilitación funcional, frente al $6,7 \%$ del grupo no tratado y en el vigésimo primer día, el $80 \%$ frente al $10 \%$ del grupo no tratado. En el dia 14 postoperatorio la actividad eléctrica del músculo masetero tratado con LBI después del trauma quirúrgico fue compatible con una condición de recuperación funcional completa. Los hallazgos de este estudio electromiográfico indicaron que el LBI es un eficiente método fisioterápico para estimular la recuperación funcional del músculo masetero tras cirugía de terceros molares mandibulares retenidos.

PALABRAS CLAVE: tercer molar, diente retenido, electromiografía, láser de baja intensidad, músculo masetero. 
SEVILHA, F. M.; DE BARROS, T. E. P.; CAMPOLONGo, G. D.; DE BARROS, T. P.; ALVES, N. \& DEANA, N. F. Electromyographic study of the masseter muscle after low-level laser therapy in patients undergoing extraction of retained lower third molars. Int. J. Odontostomat., 10(1):107-111, 2016.

\section{REFERENCES}

Alves, N. \& Cândido, P. L. Anatomia para o Cirurgião-Dentista. $2^{a}$ ed. São Paulo, Gen-Santos, 2013.

Bassanta, A. D.; Sproesser, J. G. \& de Paiva, G. Estimulação elétrica neural transcutânea ("tens"): sua aplicação nas disfunções temporo-mandibulares. Rev. Odontol. Univ. São Paulo, 11(2):109-16, 1997.

Berge, T. I. Complications requiring hospitalization after third-molar surgery. Acta Odontol. Scand., 54(1):24-8, 1996.

Brann, C. R.; Brickley, M. R. \& Shepherd, J. P. Factors influencing nerve damage during lower third molar surgery. Br. Dent. J., 186(10):514-6, 1999.

Campolongo, G. D.; de Barros, T. E.; Sevilha, F. M.; de Oliveira, R. J. \& Luz, J. G. Electromyographic study in patients with surgically treated facial fractures. J. Craniofac. Surg., 23(5):1329-32, 2012.

Cerqueira, P. R.; Vasconcelos, B. C. \& Bessa-Nogueira, R. V. Comparative study of the effect of a tube drain in impacted lower third molar surgery. J. Oral Maxillofac. Surg., 62(1):5761, 2004.

de Barros, T. E. P.; Campolongo, G. D.; de Oliveira, R. P.; Alves, N. \& de Oliveira, R. J. Electromyographic study of the masseter muscle after lower third molar surgery. Int. J. Morphol., 29(1):304-9, 2011.

Deppe, H. \& Horch, H. H. Laser applications in oral surgery and implant dentistry. Lasers Med. Sci., 22(4):217-21, 2007.

Garcia Garcia, A.; Gude Sampedro, F.; Gandara Rey, J. \& Gallas Torreira, M. Trismus and pain after removal of impacted lower third molars. J. Oral Maxillofac. Surg., 55(11):1223-6, 1997.

Goldberg, M. H.; Nemarich, A. N. \& Marco, W. P. 2nd. Complications after mandibular third molar surgery: a statistical analysis of 500 consecutive procedures in private practice. $J$. Am. Dent. Assoc., 111(2):277-9, 1985.

Hermens, H. J.; Freriks, B.; Disselhorst-Klug, C. \& Rau, G. Development of recommendations for SEMG sensors and sensor placement procedures. J. Electromyogr. Kinesiol., 10(5):361-74, 2000.

Learreta, J. A.; Arellano, J. C.; Yavich, L. G. \& La Valle, M. G. Compêndio de Diagnóstico das Patologias da atm. São Paulo, Artes Médicas, 2004.

Laureano Filho, J. R.; Camargo, I. B.; Firmo, A. C. B. \& de Oliveira e Silva, E. D. A influência do laser de baixa intensidade na redução de edema, dor e trismo no pós-operatório de cirurgia de terceiros molares inferiores inclusos: resultado preliminar com 13 casos. Rev. Cir. Traumatol. Buco-Maxilo-Fac. (Camaragibe), 8(1):47-56, 2008.
Lizarelli, R. Z. \& Lizarelli, R. F. Z. RELIZA: técnica empregando a laserterapia de baixa intensidade para tratamento básico periodontal. J. B. C. J. Bras. Clin. Odontol. Integr., 7(41):36972, 2003.

Markovic, A. \& Todorovic, Lj. Effectiveness of dexamethasone and low-power laser in minimizing oedema after third molar surgery: a clinical trial. Int. J. Oral Maxillofac. Surg., 36(3):2269, 2007.

Matamala, F.; Cornejo, R.; Paredes, M.; Farfán, E.; Garrido, O. S. \& Alves, N. Comparative Analysis of the Number of Neurofilaments in Rat Sciatic Nerve Undergoing Neuropraxia Treated by Low-Level Laser and Therapeutic Ultrasound. Int. J. Morphol., 32(1):369-74, 2014.

Mercier, P. \& Precious, D. Risks and benefits of removal of impacted third molars. A critical review of the literature. Int. J. Oral Maxillofac. Surg., 21(1):17-27, 1992.

Neiburger, E. J. Rapid healing of gingival incisions by the heliumneon diode laser. J. Mass. Dent. Soc., 48(1):8-13, 1999.

Norholt, S. E.; Aagaard, E.; Svensson, P. \& Sindet-Pedersen, S. Evaluation of trismus, bite force, and pressure algometry after third molar surgery: a placebo-controlled study of ibuprofen. J. Oral Maxillofac. Surg., 56(4):420-7, 1998.

Roynesdal, A. K.; Björnland, T.; Barkvoll, P. \& Haanaes, H. R. The effect of soft-laser application on postoperative pain and swelling. A double-blind, crossover study. Int. J. Oral Maxillofac. Surg., 22(4):242-5, 1993.

Suarez-Cunqueiro, M. M.; Gutwald, R.; Reichman, J.; OteroCepeda, X. L. \& Schmelzeisen, R. Marginal flap versus paramarginal flap in impacted third molar surgery: a prospective study. Oral Surg. Oral Med. Oral Pathol. Oral Radiol. Endod., 95(4):403-8, 2003.

Solberg, W. K. Temporomandibular disorders: physical tests in diagnosis. Br. Dent. J., 160(8):273-7, 1986.

Stolov, W. C. Eletrodiagnostic Evaluation of Acute and Chronic Pain. In: Bonica, J. A. The Management of Pain. $2^{\text {nd }}$ ed. Philadelphia, Lea and Febiger, 1990.

Viegas, V. N.; Prietto, L.; Mezzomo, L. A. M.; Abreu, M. E. R. \& Pagnoncelli, R. M. Controle do edema: terapia me77dicamentosa x uso do laser. Rev. ABO Nac., 13(4):24550, 2005

Correspondence to:

Nilton Alves

Departamento de Odontología Integral Adultos

Facultad de Odontología

Universidad de La Frontera

Francisco Salazar, 1145

Temuco

CHILE

Received: 13-08-2014

Accepted: 01-04-2016

Email: niltonnalves@yahoo.com.br 